\title{
Human C-peptide antagonises high glucose-induced endothelial dysfunction through the nuclear factor- $\kappa B$ pathway
}

\author{
P. Luppi $\cdot$ V. Cifarelli $\cdot$ H. Tse $\cdot$ J. Piganelli $\cdot$ M. Trucco
}

Received: 11 February 2008 / Accepted: 28 March 2008/Published online: 21 May 2008

(C) Springer-Verlag 2008

\begin{abstract}
Aims/hypothesis Endothelial dysfunction in diabetes is predominantly caused by hyperglycaemia leading to vascular complications through overproduction of oxidative stress and activation of the transcription factor nuclear factor- $\mathrm{KB}$ (NF-kB). Many studies have suggested that decreased circulating levels of C-peptide may play a role in diabetic vascular dysfunction. To date, the possible effects of C-peptide on endothelial cells and intracellular signalling pathways are largely unknown. We therefore investigated the effect of C-peptide on several biochemical markers of endothelial dysfunction in vitro. To gain insights into potential intracellular signalling pathways affected by C-peptide, we tested NF- $\mathrm{KB}$ activation, since it is known that inflammation, secondary to oxidative stress, is a key component of vascular complications and NF-KB is a redox-dependent transcription factor. Methods Human aortic endothelial cells (HAEC) were exposed to $25 \mathrm{mmol} / \mathrm{l}$ glucose in the presence of C-peptide $(0.5 \mathrm{nmol} / \mathrm{l})$ for $24 \mathrm{~h}$ and tested for expression of the gene encoding vascular cell adhesion molecule-1 (VCAM- 1$)$ by RT-PCR and flow cytometry. Secretion of IL-8 and monocyte chemoattractant protein-1 (MCP-1) was measured by ELISA. NF- $\mathrm{KB}$ activation was analysed by immunoblotting and ELISA.

Results Physiological concentrations of C-peptide affect high glucose-induced endothelial dysfunction by: (1) decreasing
\end{abstract}

Electronic supplementary material The online version of this article (doi:10.1007/s00125-008-1032-x) contains supplementary material, which is available to authorised users.

P. Luppi $(\varangle) \cdot$ V. Cifarelli $\cdot$ H. Tse $\cdot$ J. Piganelli $\cdot$ M. Trucco Division of Immunogenetics, Department of Pediatrics,

Rangos Research Center, Children's Hospital of Pittsburgh,

3460 Fifth Avenue,

Pittsburgh, PA 15213, USA

e-mail: luppip@pitt.edu
VCAM-1 expression and U-937 cell adherence to HAEC; (2) reducing secretion of IL-8 and MCP-1; and (3) suppressing $\mathrm{NF}-\mathrm{kB}$ activation.

Conclusions/interpretation During hyperglycaemia, Cpeptide directly affects $V C A M-1$ expression and both MCP-1 and IL-8 HAEC secretion by reducing NF-KB activation. These effects suggest a physiological anti-inflammatory (and potentially anti-atherogenic) activity of C-peptide on endothelial cells.

Keywords Atherosclerosis · C-peptide · Cytokines . Endothelial cells $\cdot$ Inflammation $\cdot$ Monocytes $\cdot$ NF- $\mathrm{KB}$. Nuclear factor $\mathrm{kB} \cdot$ Vascular smooth muscle cells

$\begin{array}{ll}\text { Abbreviations } \\ \text { EBM-2 } & \text { endothelial basal medium-2 } \\ \text { HAEC } & \text { human aortic endothelial cells } \\ \text { IKB } & \text { inhibitor } \kappa \text { B } \\ \text { MCP-1 } & \text { monocyte chemoattractant protein-1 } \\ \text { MFI } & \text { mean fluorescence intensity } \\ \text { NF- } \mathrm{KB} & \text { nuclear factor- } \mathrm{kB} \\ \text { PDTC } & \text { pyrrolidine dithiocarbamate } \\ \text { ROS } & \text { reactive oxygen species } \\ \text { VCAM-1 } & \text { vascular cell adhesion molecule-1 }\end{array}$

\section{Introduction}

Diabetes is a well-established risk factor for vascular diseases. Vascular disease in diabetes originates from common functional and structural changes in the tunica media of small (microangiopathy) as well as large vessels (macroangiopathy). In large vessels, these changes increase the probability of developing atherosclerosis, which is one of the major 
complications affecting diabetic patients. As a result of the diabetic state, the vascular compromise at small vessels level principally affects the eye, kidney and both peripheral and autonomic nerves, and this dysfunction contributes significantly to the morbidity associated with diabetes [1].

Diabetes causes vascular compromise secondary to endothelial dysfunction, measured by in vivo studies of flowmediated vasodilation [2] and increased circulating levels of biochemical markers, such as, but clearly not limited to vascular cell adhesion molecule-1 (VCAM-1) [3, 4]. Generally, VCAM-1 is expressed at a low level on endothelial cells and is upregulated upon cellular activation, such as that observed after exposure to inflammatory stimuli or high glucose $[5,6]$. VCAM-1 binds to the leucocyte integrin $\alpha_{4} \beta_{4}$ (also called very late antigen-4; CD49d) and has a principal role in the early stages of monocytes adhesion to the vascular endothelium, one of the first steps in atherosclerosis plaque formation. A major hallmark of diabetes is an abnormally elevated blood glucose level, i.e. hyperglycaemia, which has been proposed as one factor causing endothelial dysfunction in diabetes. In endothelial cells, acute and chronic hyperglycaemia works through reactive oxygen species (ROS) production $[5,7,8]$ that leads to activation of the transcription factor nuclear factor- $\mathrm{kB}$ (NF-kB) $[5,9,10]$ and ultimately the production of inflammatory mediators [11].

In the unstimulated state, NF- $\mathrm{KB}$ exists in its canonical form as a heterodimer composed of p50 and p65 subunits bound to $I \kappa \mathrm{B}$. Upon activation, I $\mathrm{KB}$ is phosphorylated and degraded causing the release of p50/p65 components of NF- $k B$ [12]. The active $\mathrm{p} 50 / \mathrm{p} 65$ heterodimer translocates to the nucleus and initiates the transcription of a gamut of genes involved in the inflammatory response, such as those encoding pro-inflammatory cytokines, cell surface adhesion molecules and chemokines, including IL-8 and monocyte chemoattractant protein-1 (MCP-1) [5, 11, 13-15]. IL-8 and MCP-1 production is present in human atherosclerotic plaques [16] and participates in the development of atherosclerosis by recruiting monocytes into the subendothelial cell layer [17].

It has been suggested that proinsulin C-peptide may possess cytoprotective effects on the microvasculature during inflammatory events [18]. In line with this, it has been reported that type 1 diabetic patients with circulating levels of C-peptide closer to the physiological level of $0.5 \mathrm{nmol} / 1$ [19] or receiving whole pancreas [20] or allogeneic islet transplantation [21] show a reduced incidence of microvascular complications. The mechanisms able to produce the beneficial effects of C-peptide on vascular dysfunction in diabetes remain largely unknown. One study performed in vivo in a rat inflammatory model of vascular dysfunction showed that a single i.v. dose of C-peptide significantly inhibited leucocyte-endothelium interaction via decreased expression of endothelial cell adhesion molecules [22], a phenomenon associated with release of nitric oxide [22, 23], which in turn has been shown to inhibit NF-KB [24]. Similar results were obtained in isolated ischaemic and reperfused rat hearts, where addition of C-peptide attenuated polymorphonuclear cell adherence to the vascular endothelium [25]. To date, no data are available on the effects of C-peptide on human endothelial cells exposed to the damaging insult of hyperglycaemia, a common condition in diabetes.

We therefore initiated a study on the direct effects of C-peptide, testing VCAM-1 expression on the cell surface, monocyte adherence and secretion of IL- 8 and MCP-1 by human aortic endothelial cells (HAEC) exposed to shortterm high glucose. Since activation of the transcription factor $\mathrm{NF}-\mathrm{kB}$ is involved in these pro-inflammatory responses, we also investigated the direct effect of C-peptide on nuclear translocation of the NF-kB subunits p50/p65 in HAEC. We hypothesised that physiological concentrations of C-peptide protect HAEC from high glucose-induced cellular dysfunction by decreasing NF-KB activation, thus inhibiting NFKB-dependent genes, such as those encoding VCAM-1, IL-8 and MCP-1.

\section{Methods}

Cell culture of HAEC HAEC were obtained from Cambrex (Cambrex Bioscience Walkersville, Walkersville, MD, USA) and grown into $75 \mathrm{~cm}^{2}$ culture flasks $(250,000$ per flask) (Corning, Corning, NY, USA) at $37^{\circ} \mathrm{C}, 5 \% \mathrm{CO}_{2}$ and in the presence of endothelial basal medium-2 (EBM-2) supplemented with endothelial growth media SingleQuots (Cambrex). HAEC were used at passages two to six.

Treatment conditions EBM-2 containing $25 \mathrm{mmol} / \mathrm{l}$ glucose (Sigma Chemical, St Louis, MO, USA) was used as a high glucose condition in all the experiments, while regular EBM-2, which contains $5.6 \mathrm{mmol} / \mathrm{l}$ glucose, was used as normal glucose condition. In all experiments, HAEC were used when having reached an $80 \%$ to $90 \%$ confluency. On the day of the experiment, cells were washed with fresh EBM-2 and then replaced with EBM-2 containing $25 \mathrm{mmol} / \mathrm{l}$ glucose in the presence or absence of physiological concentrations of human C-peptide ( 0.5 and/or $1 \mathrm{nmol} / \mathrm{l})$ (Sigma Chemical) [26] for 4 to $24 \mathrm{~h}$ in an incubator at $37^{\circ} \mathrm{C}$ and $5 \% \mathrm{CO}_{2}$. As a control for C-peptide activity, C-peptide was heat-inactivated by boiling it for $1 \mathrm{~h}$ and then added to the culture. Human recombinant TNF- $\alpha(10 \mathrm{ng} / \mathrm{ml} ; \mathrm{R} \& D$ Systems, Minneapolis, MN, USA), which activates HAEC, was used as a positive control. The effect of the NF-KB inhibitor pyrrolidine dithiocarbamate (PDTC; $10 \mu \mathrm{mol} / \mathrm{l}$; Sigma) was also tested on HAEC in certain experiments. This inhibitor was added to EBM-2 with $25 \mathrm{mmol} / 1$ glucose. Separate sets of experiments were performed in which 
C-peptide was added to regular EBM-2 containing $5.6 \mathrm{mmol} / \mathrm{l}$ glucose.

VCAM-1 detection by RT-PCR HAEC were grown into $75 \mathrm{~cm}^{2}$ culture flasks $(250,000$ per flask; Corning) and exposed to the treatment conditions mentioned above. After 4 and $24 \mathrm{~h}$, cells were trypsinised and frozen at $-80^{\circ} \mathrm{C}$. RNA extraction was performed using the RiboPure-Blood kit (Ambion, Austin, TX, USA). For RT-PCR, $1 \mu \mathrm{g}$ RNA was used together with Oligo(d)T (RETROscript; Ambion) and $1 \mu \mathrm{l}$ of cDNA was used to amplify VCAM-1. Human $G A P D H, 18 \mathrm{~S}$ ribosomal RNA and $\beta$-actin were amplified and served as internal controls [5]. Sequences of the oligonucleotides used to amplify these genes and PCR conditions are reported as Electronic supplementary material (ESM). Three independent experiments were performed. Densitometry was performed with UN-SCAN-IT gel software (Silk Scientific, Orem, UT, USA). Data are expressed as median $\pm \mathrm{SD}$.

Quantification of VCAM-1 by flow cytometry HAEC (50,000 per well) were maintained in 6-well plates (Corning) until confluent. On the day of the experiment, cells were exposed to the treatment conditions mentioned above for $24 \mathrm{~h}$. Determination of VCAM-1 expression by surface staining was performed on paraformaldehyde-fixed HAEC monolayers following a methodology shown to preserve single cell integrity [27]. A phycoerythrine-conjugated anti-human monoclonal antibody to CD106 (VCAM-1) or corresponding isotype control (BD Pharmigen, San Diego, CA, USA) were used for staining. Cells were run on a Becton Dickinson FACSCalibur and analysed at a later time (Becton Dickinson, San Jose, CA, USA). For a more detailed description of methodology and data analysis, see ESM. Three sets of independent experiments were performed. Within each experiment, each condition was tested in triplicate. Data are expressed as median $\pm \mathrm{SD}$.

Monocyte adhesion assay HAEC were grown on 48-well plates $(12,000$ per well; Corning) and exposed to the treatment conditions mentioned above for $4 \mathrm{~h}$. Human monocytic U-937 cells were purchased from the American Type Culture Collection (Rockville, MD, USA) and grown in RPMI 1640 (Cambrex) containing 10\% FCS, $100 \mu \mathrm{l} / \mathrm{ml}$ streptomycin, $100 \mathrm{IU} / \mathrm{ml}$ penicillin, $250 \mathrm{ng} / \mathrm{ml}$ fungizone, $1 \mathrm{mmol} / 1$ sodium pyruvate, $10 \mathrm{mmol} / 1 \mathrm{HEPES}$ (all from Gibco Invitrogen, Carlsbad, CA, USA) at $37^{\circ} \mathrm{C}$ and $5 \%$ of $\mathrm{CO}_{2}$. On the day of the experiment, medium was removed from each well, cells were washed with PBS and fresh medium containing U-937 cells $\left(1 \times 10^{6}\right.$ cells $\left./ \mathrm{ml}, 500 \mu \mathrm{l}\right)$ was added to each well and incubated for $1 \mathrm{~h}$ at room temperature on a rocking plate. Non-adherent U-937 cells were removed and adherent cells fixed in $1 \%$ glutaraldehyde.
The number of adherent cells was evaluated by counting three random $40 \times$ fields per well by a blinded investigator, avoiding areas of non-confluence and cell clusters. Three experiments were performed. Within each experiment, each condition was tested in triplicate. Results are showed as $\operatorname{median} \pm \mathrm{SD}$.

$I L-8$ and MCP-1 detection in culture supernatant fraction by ELISA HAEC were maintained in 6-well plates $(50,000$ per well; Corning) in EBM-2 (Cambrex). On the day of the experiment, cells were exposed to the treatment conditions mentioned above for $4 \mathrm{~h}$. The supernatant fraction was collected and kept at $-20^{\circ} \mathrm{C}$ until tested by ELISA (Quantikine; R\&D Systems). Three independent experiments were performed, in which each condition was tested in triplicate. Concentration of the chemokines $(\mathrm{pg} / \mathrm{ml}$ ) was assessed by calculating values according to the values obtained in the standard curve. Results from three separate experiments are shown as median $\pm \mathrm{SD}$.

$N F-\kappa B$ analysis assays HAEC were cultured in $75 \mathrm{~cm}^{2}$ culture flasks (250,000 per flask; Corning) and exposed to the treatment conditions as indicated above. Cells were collected at 4 and $24 \mathrm{~h}$ and pretreated with $25 \mu \mathrm{l}$ of protease inhibitor cocktail (Pierce, Rockford, IL, USA). Nuclear and cytoplasmic fractions were separated using a kit (NE-PER Nuclear and Cytoplasmic Extraction; Pierce). Protein content of the extract was measured using a bicinchoninic acid assay kit (Pierce Biotechnology). For detection of NF-kB p65 subunit by western blot, $10 \mu \mathrm{g}$ of nuclear protein extracts were used as previously described [28]. Densitometry analysis of the bands was performed with UN-SCAN-IT gel software (Silk Scientific). Activation of the NF-kB p50 subunit was detected on $3 \mu \mathrm{g}$ of nuclear protein extracts using a kit (EZ-Detect Transcription Factor Kit; Pierce Technology). For each set of data, a minimum of three experiments was performed. Data were averaged and expressed as means \pm SD.

Statistics Paired $t$ test (two-tailed) was used to analyse differences between 5.6 and $25 \mathrm{mmol} / 1$ glucose. ANOVA with the Dunnett's post hoc test was used to assess differences between $25 \mathrm{mmol} / \mathrm{l}$ glucose, C-peptide and PDTC using GraphPad Prism 4 (GraphPad Software, San Diego, CA, USA). Values of $p<0.05$ were considered to be statistically significant.

\section{Results}

C-peptide reduces VCAM-1 on HAEC exposed to high glucose In order to determine the effect of C-peptide on high glucose-stimulated VCAM-1 levels on HAEC, cells 
were treated in vitro for $24 \mathrm{~h}$ with $25 \mathrm{mmol} / \mathrm{l}$ glucose alone or in the presence of C-peptide. High glucose increased $V C A M-1$ mRNA expression compared with cells cultured in low glucose (Fig. 1a,b; $p=0.008$ ). C-peptide added to the high glucose medium inhibited $V C A M-1$ mRNA expression as compared with high glucose medium alone (Fig. 1a,b). Although both concentrations of C-peptide $(0.5$ and $1 \mathrm{nmol} / \mathrm{l})$ decreased $V C A M-1$ mRNA expression, statistical significance was reached with $0.5 \mathrm{nmol} / \mathrm{l} \mathrm{C}$-peptide only $(p<0.05)$. Heatinactivated C-peptide, used as control, did not have a significant effect on $V C A M-1$ expression (Fig. 1b). As expected, the cytokine TNF- $\alpha$ induced a dramatic upregulation of VCAM-1 expression with a threefold increase in comparison to normal glucose (Fig. 1a,b). The inhibitory effect of C-peptide on high glucose-induced stimulation of VCAM-1 mRNA in HAEC was observed as early as $4 \mathrm{~h}$ incubation (Fig. 2).

We obtained similar data by analysing VCAM- 1 expression on HAEC by flow cytometry. High glucose significantly $(p=0.03)$ changed VCAM-1 levels (average mean fluorescence intensity [MFI] $117.5 \pm 25.5 \mathrm{SD}$ ) compared with cells

a

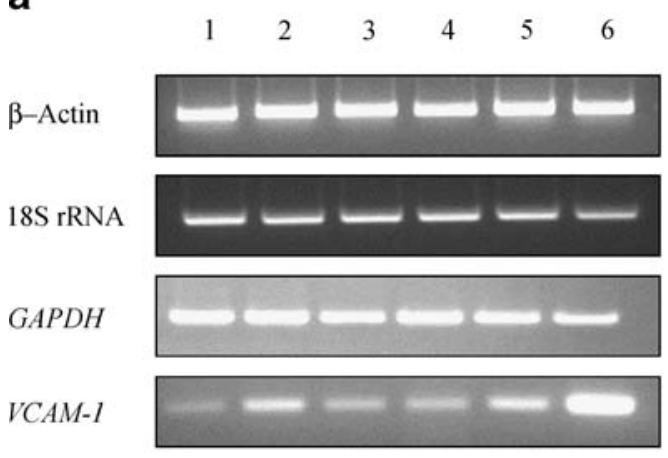

b

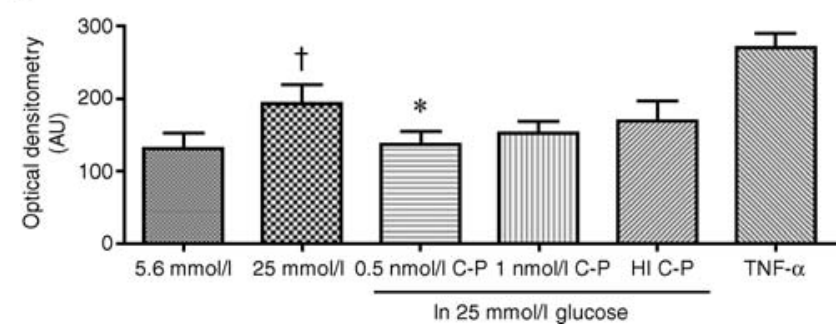

Fig. 1 C-peptide decreases high glucose-stimulated VCAM-1 mRNA after $24 \mathrm{~h}$. a RT-PCR was used to detect VCAM-1 mRNA in HAEC treated for $24 \mathrm{~h}$ with: (1) low glucose (5.6 mmol/l; LG); (2) high glucose (25 mmol/l; HG); (3) $\mathrm{HG}+0.5 \mathrm{nmol} / 1 \mathrm{C}$-peptide (C-P); (4) $\mathrm{HG}+1 \mathrm{nmol} / \mathrm{l} \mathrm{C}-\mathrm{P}$; (5) $\mathrm{HG}+1 \mathrm{nmol} / 1$ heat-inactivated (HI) C-P; (6) $\mathrm{LG}+\mathrm{TNF}-\alpha 10 \mathrm{ng} / \mathrm{ml}) . G A P D H, 18 \mathrm{~S}$ rRNA and $\beta$-actin were used as internal controls. b Densitometric analysis of VCAM-1 mRNA expression. Boxplot graphs showing the median values (limits of the lines are the 5th and 95th centiles of arbitrary units [AU]) of $V C A M-1$ mRNA in HAEC ( $n=3$ independent experiments). C-peptide decreased high glucose-induced $V C A M-1$ mRNA expression compared with high glucose alone. ${ }^{*} p<0.05, \dagger p=0.008$ vs $5.6 \mathrm{mmol} / 1$

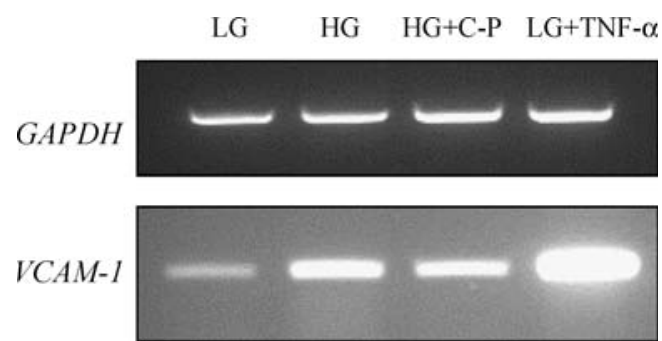

Fig. 2 C-peptide decreases high glucose-stimulated VCAM-1 mRNA after $4 \mathrm{~h}$. Representative example of RT-PCR to detect VCAM-1 mRNA expression in HAEC treated for $4 \mathrm{~h}$ with: (1) low glucose (LG; $5.6 \mathrm{mmol} / 1$ glucose); (2) high glucose (HG; $25 \mathrm{mmol} / 1$ glucose); (3) $\mathrm{HG}+0.5 \mathrm{nmol} / 1$ C-peptide (C-P); (4) LG+TNF- $\alpha 00 \mathrm{ng} / \mathrm{ml}$ ). Cpeptide reduced high glucose-stimulated VCAM-1 mRNA in HAEC. $G A P D H$ was used as an internal control

in $5.6 \mathrm{mmol} / 1$ glucose (average MFI 85.3 $\pm 2.4 \mathrm{SD}$ ) (Fig. 3a). When C-peptide was added to the $25 \mathrm{mmol} / 1$ glucose, the cell surface expression of VCAM-1 decreased (Fig. 3a). Statistical significance was reached with a C-peptide concentration of $0.5 \mathrm{nmol} / 1$ (average MFI $80.5 \pm 5.5 \mathrm{vs} 117.5 \pm 25.5 \mathrm{in}$ $25 \mathrm{mmol} / 1$ glucose alone; $p<0.01$ ). The cytokine TNF- $\alpha$ stimulated VCAM-1 expression (average MFI 305.3 \pm 115.5 SD) while heat-inactivated C-peptide did not have a significant effect on VCAM-1 (average MFI 118.8 \pm 23.2 SD).
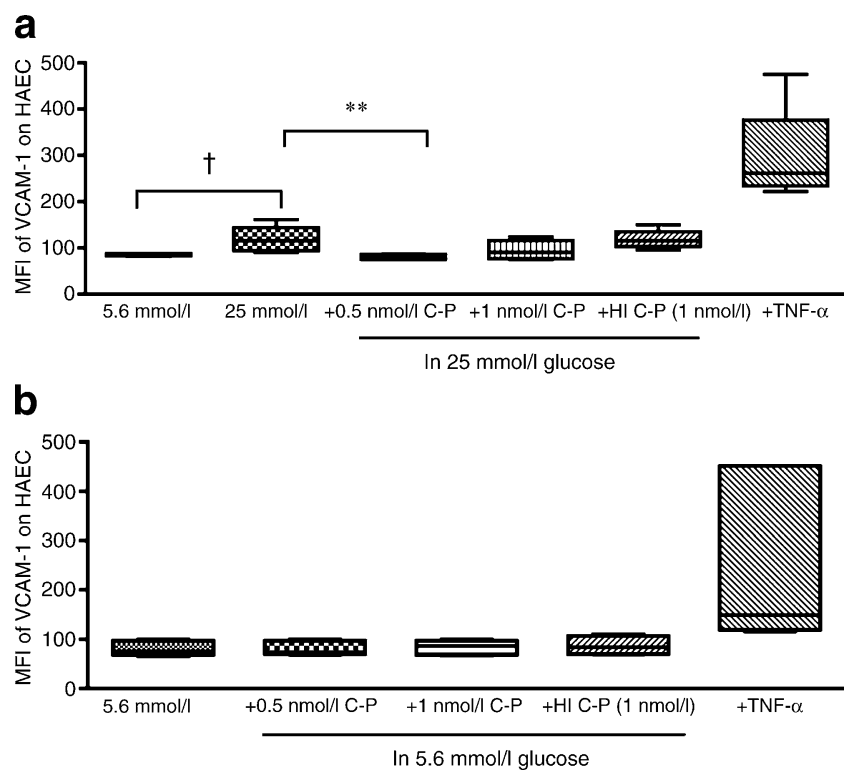

Fig. 3 C-peptide reduces high glucose-stimulated VCAM-1 protein expression on HAEC. Boxplot graphs showing the median values (limits of the lines are the 5th and 95th centiles) of MFI of VCAM-1 expression in HAEC exposed to a $25 \mathrm{mmol} / \mathrm{l}$ glucose or b $5.6 \mathrm{mmol} /$ 1 glucose with and without C-peptide (C-P) for $4 \mathrm{~h}$ as determined by flow cytometry ( $n=3$ independent experiments). a HAEC exposed to $25 \mathrm{mmol} / 1$ glucose significantly increased VCAM-1 expression; ${ }^{\dagger} p=$ $0.03 \mathrm{vs} 5.6 \mathrm{mmol} / \mathrm{l}$. This increase was significantly inhibited by $0.5 \mathrm{nmol} / 1 \mathrm{C}$-peptide; ${ }^{*} p<0.01$. No significant changes in VCAM-1 were observed when $\mathrm{C}$-peptide was added to basal medium containing $5.6 \mathrm{mmol} / \mathrm{l}$ glucose (b). HI, heat-inactivated 
When C-peptide was added to low glucose medium, it did not cause a significant change in VCAM-1 expression (Fig. 3b).

Because C-peptide at a dose of $0.5 \mathrm{nmol} / 1$ demonstrated a significant reduction in high glucose-induced VCAM-1 expression, we conducted all further experiments using this dose only.

C-peptide inhibits U-937 cells adhesion to endothelial cells To determine whether the C-peptide-induced inhibition of VCAM-1 expression on HAEC was associated with a decrease in U-937 adherence, we assessed U-937 adhesion on HAEC exposed to C-peptide under high glucose conditions. There was a threefold increase in the number of adherent U-937 under high glucose $(106 \pm 32)$ as compared with $5.6 \mathrm{mmol} / 1$ glucose $(34 \pm 8 ; p=0.004)$ (Fig. 4a). When $\mathrm{C}$-peptide was added to the high glucose medium, the number of adherent U-937 cells was reduced $(56 \pm 11 ; p<0.01$ vs $25 \mathrm{mmol} / \mathrm{l}$ glucose; Fig. 4a). Addition of heat-inactivated C-peptide did not significantly alter the number of adherent cells $(93 \pm 5)$ as compared with $25 \mathrm{mmol} / \mathrm{l}$ glucose alone. As expected, TNF- $\alpha$, which activates endothelial cells, produced a fivefold increase in U-937 adherence in comparison with HAEC exposed to normal glucose (Fig. 4a). The adhesion of U-937 to HAEC under the different conditions was also photographed (Fig. 4b).

When we evaluated the adherence of U-937 to HAEC exposed to normal glucose and with C-peptide added, we did not observe a significant change as compared with normal glucose alone (ESM Fig. 1).

C-peptide inhibits IL-8 and MCP-1 secretion by HAEC Another factor possibly affecting U-937 adherence to HAEC in the presence of C-peptide is a downregulation of secreted chemoattractant molecules by endothelial cells. As expected, we found that secretion of IL-8 in the supernatant fraction of high glucose-stimulated HAEC significantly increased $(751 \pm 99 \mathrm{pg} / \mathrm{ml})$ as compared with normal glucose (592 \pm $120 \mathrm{pg} / \mathrm{ml} ; p=0.04$; Fig. $5 \mathrm{a}$ ), while addition of C-peptide reduced IL-8 concentrations to levels equivalent to normal
Fig. 4 C-peptide reduces adhesion of U-937 to HAEC in condition of hyperglycaemia. HAEC were cultured in $25 \mathrm{mmol} / \mathrm{l}$ glucose in the presence or absence of $0.5 \mathrm{nmol} / 1$ of C-peptide (C-P) for $4 \mathrm{~h}$. U-937 were added for $1 \mathrm{~h}$ and then counted. a Boxplot graphs showing the median values (limits of the lines are 5th and 95th centiles) of number of adherent U-937 per well $(n=3$ sets of independent experiments). High glucose increased the number of adherent U-937; ${ }^{\dagger} p=0.004$ vs $5.6 \mathrm{mmol} / \mathrm{l} \mathrm{glu}-$ cose. Addition of C-peptide reduced the number of adherent $\mathrm{U}-937 ; * *<<0.01$ vs $25 \mathrm{mmol} /$ 1 glucose alone. Heat-inactivated (HI) C-peptide $(0.5 \mathrm{nmol} / \mathrm{l}) \mathrm{did}$ not significantly alter adherence of U-937. TNF- $\alpha(10 \mathrm{ng} / \mathrm{ml})$ produced more than a fivefold increase in adherent U-937 in comparison to normal glucose. b Photographic view of U-937 adherent to HAEC

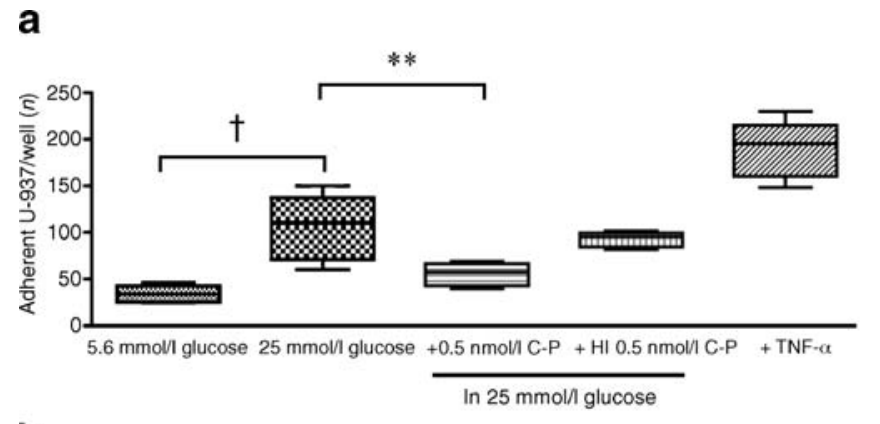

b
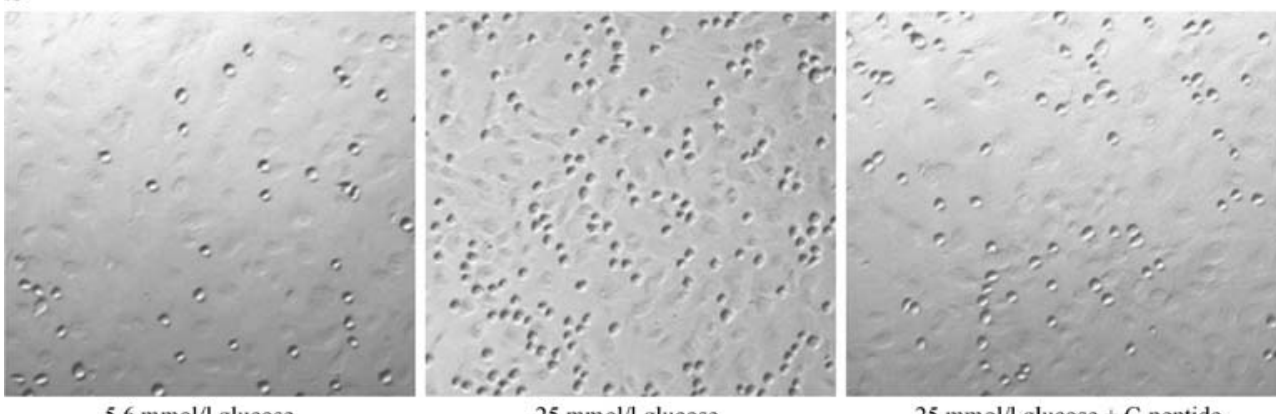

$5.6 \mathrm{mmol} / \mathrm{l}$ glucose

$25 \mathrm{mmol} / 1$ glucose

$25 \mathrm{mmol} / \mathrm{l}$ glucose $+\mathrm{C}$-peptide

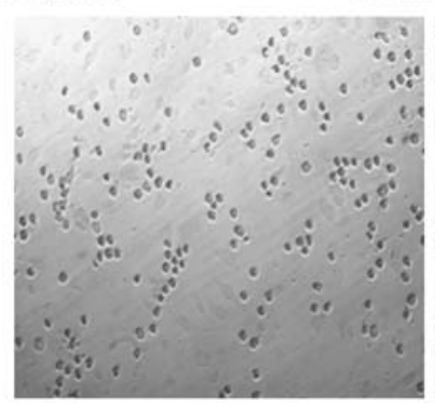

$25 \mathrm{mmol} / 1$ glucose + HI C-Peptide

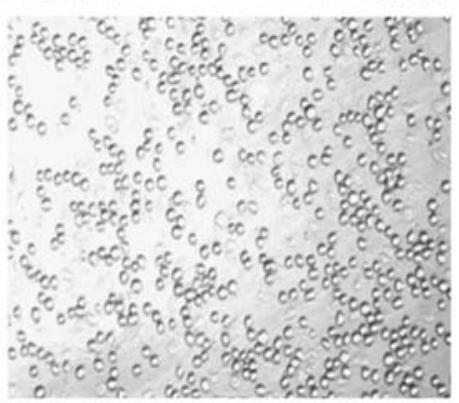

$25 \mathrm{mmol} / \mathrm{l}$ glucose $+\mathrm{TNF}-\alpha$ 
glucose $(p<0.05$; Fig. $5 b)$. The heat-inactivated C-peptide control had no significant effect (Fig. 5b). The high glucoseinduced IL- 8 secretion by HAEC was mediated by NF- $\mathrm{kB}$ activation since treatment with PDTC $(10 \mu \mathrm{mol} / \mathrm{l})$, an NF-kB inhibitor, reduced IL-8 secretion to basal levels also detected in normal glucose ( $p<0.01$ vs $25 \mathrm{mmol} / \mathrm{l}$ glucose; Fig. $5 b)$.

Similarly, when HAEC were stimulated with high glucose for $4 \mathrm{~h}$, secretion of MCP-1 increased (472 \pm $89 \mathrm{pg} / \mathrm{ml})$ as compared with normal glucose $(329 \pm 152 \mathrm{pg} / \mathrm{ml}$; $p=0.01$; Fig. 6a). Addition of C-peptide, decreased MCP-1 concentrations to those found with normal glucose levels $(p<0.05$; Fig. $6 \mathrm{~b})$. Here, too, the specific-NF- $\mathrm{kB}$ inhibitor PDTC $\mu \mathrm{mol} / \mathrm{l})$ decreased MCP-1 levels dramatically $(p<0.01$ vs $25 \mathrm{mmol} / \mathrm{l}$ glucose; Fig. 6b).

C-peptide added to regular medium containing low glucose failed to significantly modify IL- 8 and MCP-1 secretion compared with basal medium without C-peptide (ESM Fig. 2).

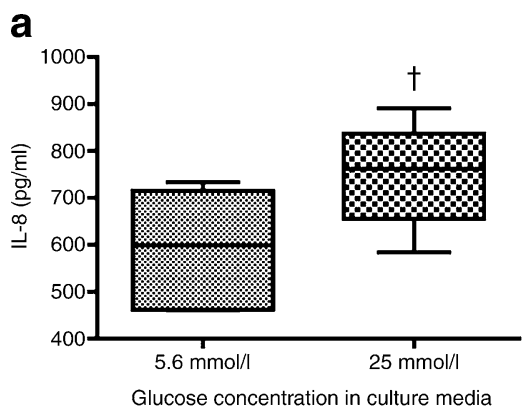

b

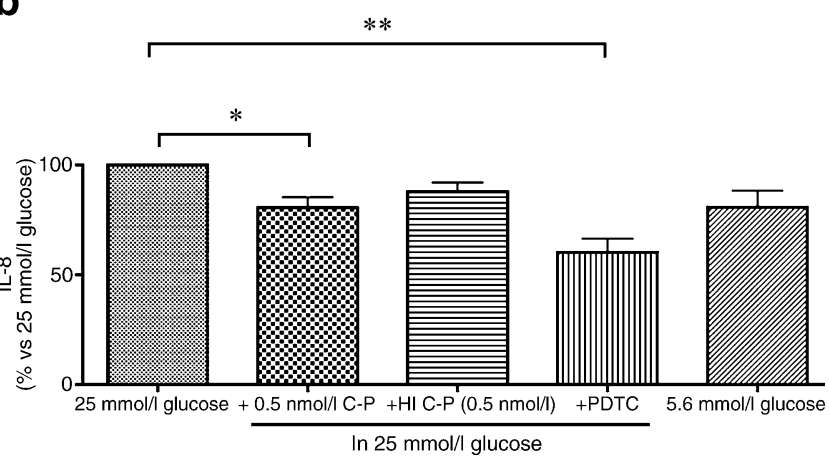

Fig. 5 C-peptide decreases high glucose-stimulated IL-8 secretion by HAEC. HAEC were cultured with high glucose (HG; $25 \mathrm{mmol} / \mathrm{l}$ ) alone or combined with C-peptide (C-P; $0.5 \mathrm{nmol} / \mathrm{l}$ ) for $4 \mathrm{~h}$ and secretion of IL-8 in the supernatant fraction was assessed by ELISA. a Boxplot graph showing the median values (limits of the lines are 5th and 95th centiles) of secreted IL-8 in the supernatant fraction of HAEC exposed to HG compared with low glucose $(5.6 \mathrm{mmol} / \mathrm{l}) ;{ }^{\dagger} p=$ 0.04. b Levels of IL-8 in supernatant fraction of C-peptide-treated HAEC expressed as per cent versus the appropriate control at $25 \mathrm{mmol} / \mathrm{l}$. HAEC treated with high glucose $+\mathrm{C}$-peptide showed a decrease in secreted IL-8, approaching levels measured in low glucose; $* p<0.05$ vs high glucose. A significant decrease in secreted IL-8 was also found in the presence of the NF- $\mathrm{KB}$ inhibitor PDTC $(10 \mu \mathrm{mol} / 1) ; * *<0.01$. The average $\pm \mathrm{SD}$ of a set of three independent experiments run in triplicate are shown. HI, heat-inactivated

\section{a}

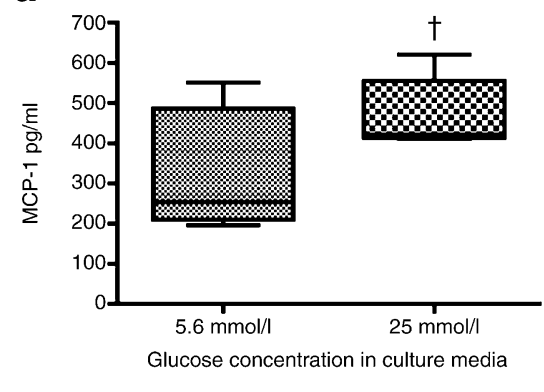

b

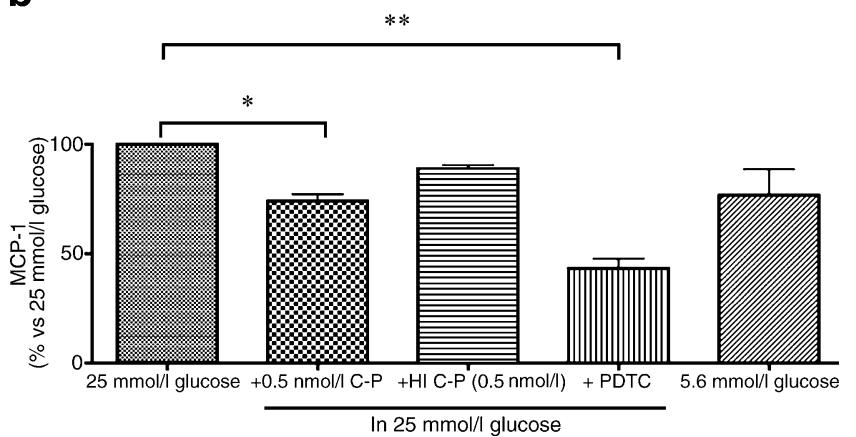

Fig. 6 C-peptide decreases high glucose-stimulated MCP-1 secretion by HAEC. HAEC were cultured with high glucose (HG; $25 \mathrm{mmol} / \mathrm{l}$ ) alone (a) or combined (b) with C-peptide (C-P; $0.5 \mathrm{nmol} / \mathrm{l})$ for $4 \mathrm{~h}$ and secretion of MCP-1 in the supernatant fraction was assessed by ELISA. a Boxplot graph showing the median values (limits of the lines are 5th and 95th centiles) of secreted MCP-1 in the supernatant fraction of HAEC exposed to $\mathrm{HG}$ compared with low glucose $(5.6 \mathrm{mmol} / 1) ;{ }^{\dagger} p=0.04$. b Levels of MCP-1 in supernatant fraction of $\mathrm{C}$-peptide-treated HAEC expressed as per cent versus the appropriate control at $25 \mathrm{mmol} / \mathrm{l}$. When cells were treated with $\mathrm{HG}+\mathrm{C}$-peptide the secretion of MCP-1 decreased; ${ }^{*} p<0.05$ vs HG. A dramatic decrease in MCP-1 secretion was obtained with the NF- $\mathrm{kB}$ inhibitor PDTC $(10 \mu \mathrm{mol} / 1) ;{ }^{* *} p<0.01$. The average $\pm \mathrm{SD}$ of a set of three independent experiments run in triplicate are shown. HI, heat-inactivated

C-peptide decreases high glucose-induced NF- $\kappa B$ translocation in HAEC The signal transduction pathway leading to mRNA synthesis of adhesion molecules and chemokines involves activation of NF- $\mathrm{kB}$. To determine whether C-peptide affected high glucose-induced NF- $\mathrm{kB}$ nuclear translocation in HAEC, immunoblot analysis and NF-kB-specific ELISAs were performed with nuclear extracts from stimulatedHAEC. As shown in Fig. 7a, exposure of HAEC to $25 \mathrm{mmol} / \mathrm{l}$ for $4 \mathrm{~h}$ induced an increase in NF-kB nuclear translocation in comparison to $5.6 \mathrm{mmol} / 1$ glucose. A twofold increase in NF-kB p65 activation was found after $24 \mathrm{~h}$ incubation with $25 \mathrm{mmol} / \mathrm{l}$ glucose $(p=0.03$ vs $5.6 \mathrm{mmol} / \mathrm{l}$; Fig. 7a). Addition of C-peptide to high glucose decreased NF-kB p65 nuclear translocation to that found with normal glucose levels, while heat-inactivated C-peptide did not suppress NF-KB activity (Fig. 7a). Densitometric analysis of this NF-kB p65 immunoblot demonstrated that C-peptide reduced NF-KB p65 nuclear translocation by twofold as compared with high glucose alone $(p<0.05$; Fig. $7 \mathrm{c})$. 
a

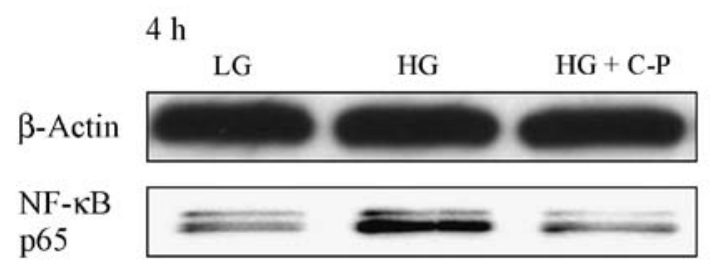

b

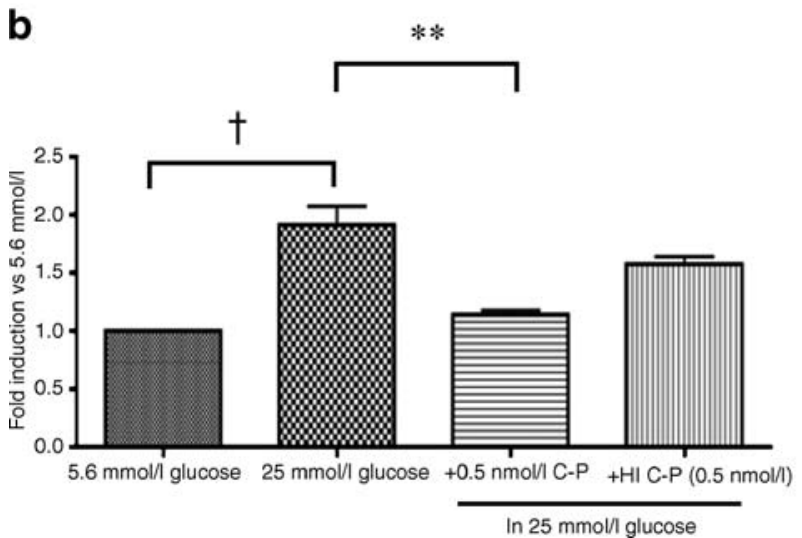

Fig. 7 C-peptide reduces levels of NF-kB p65/p50 in HAEC cultured in high glucose. HAEC were cultured in low glucose (LG; $5.6 \mathrm{mmol} / \mathrm{l})$ or high glucose $(\mathrm{HG} ; 25 \mathrm{mmol} / \mathrm{l})$ in the presence or absence of $0.5 \mathrm{nmol} / 1 \mathrm{C}$-peptide (C-P) for 4 and $24 \mathrm{~h}$. Cellular nuclear extracts were subjected to a Western immunoblotting to detect the $65 \mathrm{kDa}$ band of the p65 subunit after 4 and $24 \mathrm{~h}$. b Detection of the NF-kB p50 binding activity by ELISA after $24 \mathrm{~h}$. Results are expressed as fold induction of NF-kB p50 activity in respect to $5.6 \mathrm{mmol} / \mathrm{l}$ glucose. In cells exposed to $\mathrm{HG}$ there was a twofold increase in NF- $\mathrm{KB}$ p50 nuclear translocation compared with cells in $\mathrm{LG} ;{ }^{\dagger} p=0.002$. A

Activation of the NF-KB p50 subunit in glucosestimulated HAEC was assessed by ELISA. As shown in Fig. 7b, high glucose significantly induced NF- $\mathrm{kB}$ p50 activity in contrast to normal glucose $(p=0.002)$. High glucose-induced NF-KB p50 binding activity was efficiently ablated by the addition of C-peptide $(p<0.01)$.

\section{Discussion}

Type 1 diabetes patients have an increased risk of developing atherosclerosis and microvascular complications compared with the non-diabetic population. This risk is in part associated with the difficulty in maintaining euglycaemic conditions even in the context of an appropriate exogenous insulin treatment [29]. Recombinant insulin does not contain C-peptide, a product of insulin protein biosynthesis that exerts beneficial effects on some of the microvascular complications associated with diabetes [30-32].

In this study, we investigated the impact of human Cpeptide specifically in the early process of atherogenesis. The few studies available on the topic have tested the effect of C-peptide on low and high glucose-induced proliferative
$24 \mathrm{~h}$
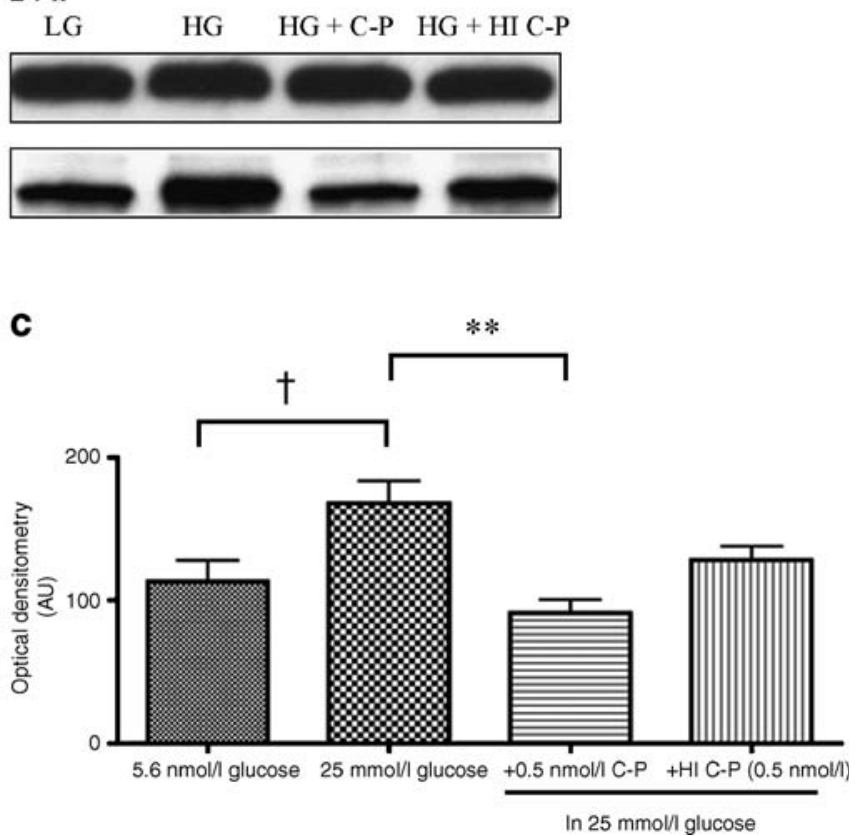

decrease in NF- $\mathrm{KB}$ p50 nuclear translocation was observed in the presence of $0.5 \mathrm{nmol} / 1 \mathrm{C}$-peptide (C-P); ${ }^{* *} p<0.01$ vs HG alone. $\mathbf{c}$ Bar graph showing the densitometric quantification in arbitrary units (AU) of the bands at $24 \mathrm{~h}$. In cells exposed to $\mathrm{HG}$ there was a twofold increase in NF- $\mathrm{kB}$ p65 nuclear translocation compared with cells in LG; ${ }^{\dagger} p=0.03$. A decrease in $\mathrm{p} 65$ nuclear translocation was observed in the presence of $0.5 \mathrm{nmol} / 1 \mathrm{C}-\mathrm{P}:{ }^{*} p<0.05$ vs HG alone. Results are expressed as means $\pm \mathrm{SD}(n=3)$. Heat-inactivated (HI) C-peptide was used as a control for C-peptide activity in all the experiments

activities of vascular smooth muscle cells, one major component involved in the formation of atherosclerotic plaque $[33,34]$. Here, we wanted to expand upon these studies by evaluating the potential effects of C-peptide on the endothelial cell component of the vessel wall during hyperglycaemia.

The adhesion and migration of circulating monocytes into the subendothelial space is one of the key events in the early stages of atherogenesis [35]. This process is in part regulated by the expression of adhesion molecules, such as VCAM-1, on the surface of endothelial cells [36], and by the release of chemotactic factors, including IL- 8 and MCP-1 [17]. We found that in vitro C-peptide exerts an inhibitory effect on high glucose-induced upregulation of the adhesion molecule VCAM-1 on HAEC. C-peptide at the physiological concentration of $0.5 \mathrm{nmol} / \mathrm{l}$ reduced high glucose-induced expression of VCAM-1 to basal levels observed under normal glucose conditions. This effect was observed as early as $4 \mathrm{~h}$ after $\mathrm{C}$-peptide addition to the high glucose medium and was still detected after $24 \mathrm{~h}$ incubation. The decrease in high glucose-induced VCAM-1 expression by C-peptide on HAEC was detected both at the mRNA and protein level. Conversely, when C-peptide was added to the 
medium containing normal glucose levels, it failed to significantly reduce VCAM-1 expression. These results are in line with findings from another group demonstrating that C-peptide reduced expression of the adhesion molecules P-selectin and intercellular adhesion molecule-1 on the rat microvascular endothelium during acute endothelial dysfunction in vivo [22]. In another model of vascular injury, C-peptide was shown to decrease polymorphonuclear leucocyte infiltration into the myocardium thereby improving cardiac dysfunction [25]. Overall, these data seem to point to an anti-inflammatory effect of C-peptide on the endothelium, especially in conditions of insult. This hypothesis is supported by recent in vivo data showing that survival rates of mice following endotoxic shock is improved after C-peptide administration [37]. In these mice, plasma levels of the pro-inflammatory cytokines TNF- $\alpha$ and MCP-1 were also decreased, suggesting a decreased generalised inflammatory response [37]. In the context of type 1 diabetes patients, upregulation of endothelial VCAM-1 and inflammation are early events in the course of the disease [2, 3840]. These patients are insulin-dependent and take exogenous insulin to manage their blood glucose levels. It might well be that addition of physiological levels of C-peptide to the traditional exogenous insulin therapy could be a means of 'counteracting' the insult of high glucose on the endothelial cells of diabetic patients.

Another component of endothelial dysfunction affected by C-peptide is the secretion of IL- 8 and MCP-1, chemokines that facilitate leucocyte-endothelial interactions. In support of other investigators $[5,6,16]$, we observed an increased secretion of both chemokines in the supernatant fraction of endothelial cells under high glucose. Unique to this study, however, is the finding that C-peptide reduced high glucose-stimulated IL-8 and MCP-1 secretion by endothelial cells to near or below the basal levels measured under normal glucose concentrations. Based on our findings, it seems that C-peptide might exert its most meaningful biological effects on the endothelium in conditions of insult, as C-peptide did not significantly change chemokine secretion by HAEC when added to normal glucose-containing medium. In addition, adhesion of U-937 cells to high glucose-stimulated HAEC decreased after addition of C-peptide, an effect not detected when C-peptide was heatinactivated. C-peptide at $0.5 \mathrm{nmol} / 1$ suppressed U-937 attachment to HAEC exposed to $25 \mathrm{mmol} / \mathrm{l}$ glucose by $50 \%$ due to a C-peptide-mediated inhibitory effect on VCAM-1, IL-8 and MCP-1 secretion by endothelial cells. Although in this study we focused on the effects of C-peptide on high glucose-induced endothelial dysfunction, another likely cellular target of $\mathrm{C}$-peptide action in diabetes could be the immune cells. Previous studies from our laboratory [41] and others [42] have shown that phenotypic changes suggestive of cellular activation are present in circulating monocytes of recently diagnosed type 1 diabetes patients. It is tempting to speculate that in conditions of hyperglycaemia and the underlying inflammation typical of diabetes, C-peptide might exert beneficial effects on both endothelial and immune cell dysfunction, thereby decreasing the overall risk of developing vascular lesions. The biological effect of C-peptide on immune cells is currently under investigation in our laboratory.

The mechanisms underlying the effects of C-peptide on the human vasculature, specifically on endothelial cells, are still largely unknown. Nevertheless, the signal transduction pathways that lead to the enhanced expression of genes encoding adhesion molecules and inflammatory cytokine secretion in endothelial cells require translocation of the transcription factor NF-KB [13]. Therefore, this study investigated C-peptide effects on NF- $\mathrm{KB}$ activation in high glucose-stimulated HAEC. In support of a previous study [5], we confirm that short-term high glucose exposure of endothelial cells stimulates NF-KB activation. However, our work has moved the paradigm forward by demonstrating that exogenous addition of C-peptide significantly reduced high glucose-induced nuclear translocation of canonical components of NF-kB, p65 and p50. The suppressive effect on NF- $\mathrm{KB}$ activation and high glucose-induced VCAM-1 expression as well as IL-8 and MCP-1 secretion in HAEC was specific for C-peptide, since heat-inactivated C-peptide was not able to elicit the same phenotype. Although we did not investigate the precise mechanism of action of C-peptide on the inhibition of NF-KB nuclear translocation in HAEC, evidence of cellular internalisation and binding to intracellular components has been recently demonstrated in Swiss 3 T3 and HEK-293 cells [43]. In the same study, interestingly, C-peptide was also shown to localise within the nuclei [43]. We can therefore speculate that the inhibitory action of C-peptide on NF- $\mathrm{kB}$ activation in HAEC could result from an effect on the phosphorylation of protein substrates in the cytoplasm and/or of a direct interaction of C-peptide with NF-KB p65/p50 subunits at the nuclear level, preventing DNA binding. In the lung of endotoxintreated mice, C-peptide inhibited phosphorylation of extracellular signal-regulated kinase-1/2 followed by upregulation of nuclear levels and DNA binding of the nuclear transcription factor peroxisome proliferator-activated receptor- $\gamma$, which plays an important role in the modulation of inflammation [37]. Currently, we are exploring which NF-kB-dependent upstream signalling events are affected by $\mathrm{C}$-peptide in endothelial cells; examples are ROS generation and IKB kinase, an enzyme that elicits phosphorylation of the cytosolic $N F-\kappa B$ inhibitor $I \kappa B \alpha$. This latter upstream event regulates $\mathrm{NF}-\mathrm{KB}$ translocation from the cytoplasm to the nucleus. In vascular smooth muscle cells we found that $\mathrm{C}$-peptide reduced high glucose-induced phosphorylation of IKB $\alpha$ [44], a pathway likely to be also targeted in HAEC. 
Inhibition of NF- $\mathrm{KB}$ would be suggestive of an antiinflammatory effect of physiological concentrations of Cpeptide at the endothelial cell level $[19,22]$ and would be consistent with a potential anti-atherosclerotic effect in type 1 diabetes. Higher supra-physiological levels of circulating C-peptide, such as those measured in type 2 diabetic patients with the hyperinsulinaemia associated with insulin resistance, might have deleterious effects on the vasculature. This view is supported by Walcher et al. [45], who found that higher concentrations of C-peptide, mimicking those found in the circulation of type 2 diabetic patients, produced maximal stimulation of lymphocyte chemotaxis in vitro. Future studies are required to further elucidate these issues.

Although this evidence in human endothelial cells is reported here for the first time, a protective effect of C-peptide on high glucose-induced vascular dysfunction has been invoked by other groups, who tested the efficacy of C-peptide in small clinical trials of type 1 diabetic patients [30-32, 46]. In addition to endothelial cells, vascular smooth muscle cells also appear to be the target of beneficial effects of C-peptide on the vasculature in conditions of hyperglycaemia [33, 44]. Physiological concentrations of C-peptide attenuate glucoseinduced hyperproliferation of vascular smooth muscle cells $[33,44]$, a phenomenon associated, at least in part, with a specific inhibitory effect on NF-KB [44].

In conclusion, our findings support the hypothesis that C-peptide has major physiological effects on the inhibition of endothelial dysfunction under high glucose conditions. It does this by interfering with NF- $\mathrm{KB}$ activation and its effect on the reduced production of pro-inflammatory cytokines and chemokines. These findings underscore a role of C-peptide in endothelial cell functions, especially in conditions of diabetic insult to the vasculature. Our results support the idea of prolonged administration of physiological quantities of C-peptide to type 1 diabetes patients in an effort to lessen endothelial dysfunction and complications that may potentially arise during the course of the disease.

Acknowledgements This study was supported by the Henry Hillman Endowment Chair in Pediatric Immunology (to M. Trucco) and by grants DK 024021-24 from the National Institute of Health and NIH 5K12 DK063704 (to P. Luppi and M. Trucco) and W81XWH-061-0317 from the Department of Defense (M. Trucco)

Duality of interest The authors declare that there is no duality of interest associated with this manuscript.

\section{References}

1. Zatz R, Brenner BM (1986) Pathogenesis of diabetic microangiopathy: The hemodynamic view. Am J Med 80:443-453

2. Jarvisalo MJ, Raitakari M, Toikka JO et al (2004) Endothelial dysfunction and increased arterial intima-media thickness in children with type 1 diabetes. Circulation 109:1750-1755
3. Schmidt AM, Crandall J, Hori O, Cao R, Lakatta E (1996) Elevated plasma levels of vascular cell adhesion molecule-1 (VCAM-1) in diabetic patients with microalbuminuria: a marker of vascular dysfunction and progressive vascular disease. $\mathrm{Br} \mathrm{J}$ Hematol 92:747-750

4. Jude EB, Douglas JT, Anderson SG, Young MJ, Boulton AJ (2002) Circulating cellular adhesion molecules ICAM-1, VCAM$1, \mathrm{P}$ - and E-selectin in the prediction of cardiovascular disease in diabetes mellitus. Eur J Intern Med 13:185-189

5. Piga R, Naito Y, Kokura O, Yoshikawa T (2007) Short-term high glucose exposure induces monocyte-endothelial cells adhesion and transmigration by increasing VCAM-1 and MCP-1 expression in human aortic endothelial cells. Atherosclerosis 193:328-334

6. Haubner F, Lehle K, Munzel D, Schmid C, Birnbaum D, Preuner JG (2007) Hyperglycemia increases the levels of vascular cellular adhesion molecule- 1 and monocyte-chemoattractant-protein- 1 in the diabetic endothelial cell. Biochem Bioph Res Commun 360:560-565

7. Inoguchi T, Li P, Umeda F et al (2000) High glucose level and free fatty acid stimulate reactive oxygen species production through protein kinase C-dependent activation of $\mathrm{NAD}(\mathrm{P}) \mathrm{H}$ oxidase in cultured vascular cells. Diabetes 49:1939-1945

8. Yano M, Hasegawa G, Ishii M et al (2004) Short-term exposure of high glucose concentration induces generation of reactive oxygen species in endothelial cells: implication for the oxidative stress associated with postprandial hyperglycemia. Redox Rep 9:111-116

9. Janssen-Heininger YM, Poynter ME, Baeuerle PA (2000) Recent advances towards understanding redox mechanisms in the activation of nuclear factor kappaB. Free Radic Biol Med 28:1317-1327

10. Nishikawa T, Eldestein D, Dux XL et al (2000) Normalizing mitochondrial superoxide production blocks three pathways of hyperglycaemic damage. Nature 404:787-790

11. Soares MP, Muniappan A, Kaczmarek E et al (1998) Adenovirusmediated expression of a dominant negative mutant of p65/RelA inhibits proinflammatory gene expression in endothelial cells without sensitizing for apoptosis. J Immunol 161:4572-4582

12. Viatour P, Merville MP, Bours V, Chariot A (2005) Phosphorylation of NF-kappaB and IkappaB proteins: implications in cancer and inflammation. Trends Biochem Sci 30:43-52

13. Tak PP, Firestein GS (2001) NF-kB: a key role in inflammatory diseases. J Clin Invest 107:7-11

14. Harada C, Okumura A, Namekata K et al (2006) Role of monocyte chemotactic protein-1 and nuclear factor kappa B in the pathogenesis of proliferative diabetic retinopathy. Diabetes Res Clin Practice $74: 249-256$

15. Srinivasan S, Yeh M, Danzinger EC et al (2003) Glucose regulates monocyte adhesion through endothelial production of interleukin8. Cir Res 92:371-377

16. Wilcox JN, Nelken NA, Coughlin SR, Gordon D, Schall TJ (1994) Local expression of inflammatory cytokines in human atherosclerotic plaques. J Atheroscler Thromb 1(Suppl 1):S10-S13

17. Gerszten RE, Garcia-Zepeda EA, Lim Y-C et al (1999) MCP-1 and IL-8 trigger firm adhesion of monocytes to vascular endothelium under flow conditions. Nature 398:718-723

18. Wahren J, Ekberg K, Jornvall H (2007) C-peptide is a bioactive peptide. Diabetologia 50:503-509

19. Steffes MW, Sibley S, Jackson M, Thomas W (2003) Beta-cell function and the development of diabetes-related complications in the diabetes control and complications trial. Diabetes Care 26: $832-836$

20. Lee TC, Barshes NR, Agee EE, O’Mahoney CA, Brunicardi FC, Goss JA (2006) The effect of whole organ pancreas transplantation and PIT on diabetic complications. Curr Diab Rep 6:323-327

21. Shapiro AM, Ricordi C, Hering BJ et al (2006) International trial of the Edmonton protocol for islet transplantation. N Engl J Med $355: 1318-1330$ 
22. Scalia R, Coyle KM, Levin BL, Booth G, Lefer AM (2000) C-peptide inhibits leukocyte endothelium interaction in the microcirculation during acute endothelial dysfunction. FASEB J 14:2357-2364

23. Gauthier TW, Scalia R, Murohara T, Guo JP, Lefer AM (1995) Nitric oxide protects against leukocyte-endothelium interactions in the early stages of hypercholesterolemia. Arterioscl Thromb Vasc Biol 15:1652-1659

24. De Caterina R, Libby P, Peng HB et al (1995) Nitric oxide decreases cytokine-induced endothelial activation. Nitric oxide selectively reduces endothelial expression of adhesion molecules and proinflammatory cytokines. J Clin Invest 96:60-68

25. Young LH, Ikeda Y, Scalia R, Lefer AM (2000) C-pepide exerts cardioprotective effects in myocardial ischemia-reperfusion. Am J Physiol Heart Circ Physiol 279:H1453-H1459

26. Rigler R, Pramanik A, Jonasson P et al (1999) Specific binding of proinsulin C-peptide to human cell membranes. Proc Natl Acad Sci U S A 96:13318-13323

27. Grabner R, Till U, Heller R (2000) Flow cytometric determination of E-selectin, Vascular cell adhesion molecule-1, and intercellular cell adhesion molecule-1 in formaldehyde-fixed endothelial cell monolayers. Cytometry 40:238-244

28. Tse HM, Milton MJ, Piganelli JD (2004) Mechanistic analysis of the immunomodulatory effects of a catalytic antioxidant on antigen-presenting cells: implication for their use in targeting oxidation-reduction reactions in innate immunity. Free Radic Biol Med 36:233-247

29. Diabetes Control and Complications Trial Research Group (1993) The effect of intensive treatment of diabetes on the development and progression of long-term complications in insulin-dependent diabetes mellitus. N Engl J Med 329:977-986

30. Johansson BL, Borg K, Fernqvist-Forbes E, Kernell A, Odergren T, Wahren J (2000) Beneficial effects of C-peptide on incipient nephropathy and neuropathy in patients with type 1 diabetes: a three-month study. Diabet Med 17:181-189

31. Ekberg K, Brismar T, Johansson BL et al (2007) C-Peptide replacement therapy and sensory nerve function in type 1 diabetic neuropathy. Diabetes Care 30:71-76

32. Hansen A, Johansson BL, Wahren J, von Bibra H (2002) Cpeptide exerts beneficial effects on myocardial blood flow and function in patients with type 1 diabetes. Diabetes 51:3077-3082

33. Kobayashi Y, Naruse K, Hamada Y et al (2005) Human proinsulin C-peptide prevents proliferation of rat aortic smooth muscle cells cultured in high-glucose conditions. Diabetologia 48:2396-2401

34. Walcher D, Babiak C, Poletek P et al (2006) C-peptide induces vascular smooth muscle cell proliferation: Involvement of
Src-kinase, phosphatidylinositol 3-kinase, and extracellular signalregulated kinase 1/2. Circulation Res 99:1181-1187

35. Gerrity RG (1981) The role of the monocyte in atherogenesis: II. Migration of foam cells from atherosclerotic lesions. Am J Pathol 103:191-200

36. Dansky HM, Barlow CB, Lominska C et al (2001) Adhesion of monocytes to arterial endothelium and initiation of atherosclerosis are critically dependent on vascular cell adhesion molecule-1 gene dosage. Arterioscler Thromb Vasc Biol 21:1662-1667

37. Vish M, Mangeshkar P, Piraino G et al (2007) Proinsulin C-peptide exerts beneficial effects in endotoxic shock in mice. Critic Care Med 35:1348-1355

38. Elhadd TA, Kennedy G, Hill A et al (1999) Abnormal markers of endothelial cell activation and oxidative stress in children adolescents and young adults with type 1 diabetes with no clinical vascular disease. Diabetes Metab Res Rev 15:405-411

39. Toivonen A, Kulmala P, Savola K, Akerblom HK, Knip M, The Childhood Diabetes In Finland Study Group (2001) Soluble adhesion molecules in preclinical type 1 diabetes. The Childhood Diabetes in Finland Study Group. Pediatr Res 49:24-29

40. Devaraj S, Cheung AT, Jialal I et al (2007) Evidence of increased inflammation and microcirculatory abnormalities in patients with type 1 diabetes and their role in microvascular complications. Diabetes 56:2790-2796

41. Cifarelli V, Libman IM, DeLuca A, Becker D, Trucco M, Luppi P (2007) Increased expression of monocyte CD11b (Mac-1) in overweight recent-onset type 1 diabetic children. Rev Diabet Stud $4: 112-117$

42. Kunt T, Forst T, Fruh B et al (1999) Binding of monocytes from normolipidemic patients with type 1 diabetes to endothelial cells is increased in vivo. Exp Clin Endocrinol Diabetes 107:252-256

43. Lindahl E, Nyman U, Melles E et al (2007) Cellular internalization of proinsulin C-peptide. Cell Mole Life Sci 64:479-486

44. Cifarelli V, Luppi P, Tse MT, He J, Piganelli J, Trucco M (2008) Human proinsulin C-peptide reduces high glucose-induced proliferation and NF-KB activation in vascular smooth muscle cells. Atherosclerosis. DOI 10.1016/j.atherosclerosis.2007.12.060

45. Walcher D, Aleksie M, Jerg V et al (2004) C-peptide induces chemotaxis of human CD4-positive cells: involvement of pertussis toxin-sensitive G-proteins and phosphoinositide 3-kinase. Diabetes 53:1664-1670

46. Johansson BL, Wahren J, Pernow J (2003) C-peptide increases forearm blood flow in patients with type 1 diabetes via a nitric oxide-dependent mechanism. Am J Physiol Endocrinol Metab 285: E864-E870 